\title{
A population-based study on binge drinking among elderly Brazilian men: evidence from the Belo Horizonte and Bambuí health surveys
}

\section{Estudo de base populacional sobre consumo excessivo de álcool entre homens idosos: evidências dos inquéritos de saúde de Belo Horizonte e Bambuí}

\author{
Hugo A C Prais, ${ }^{1,2}$ Antônio Iǵnácio de Loyola Filho, ${ }^{1,2}$ Josélia 0 A Firmo, ${ }^{1,2}$ \\ Maria Fernanda Lima-Costa, ${ }^{1,2,3}$ Elizabeth Uchoa ${ }^{1,2,4}$
}

\begin{abstract}
Objectives: To assess the prevalence and factors associated with binge drinking in two populations of older adults ( $\geq 60$ years). Method: A random sample of 685 subjects in the metropolitan area of Belo Horizonte (4.4 million inhabitants) and 643 subjects (92.7\% from total residents) in Bambui City (15,000 inhabitants), both in Southeast Brazil, participated in the study. The dependent variable was binge drinking ( $\geq 5$ drinks on a single occasion in the last 30 days), and independent variables included sociodemographic characteristics, social network, health conditions and use of health services. Results: The prevalence of binge drinking was higher in the metropolitan area of Belo Horizonte (27.0\%) than in Bambui (13.7\%). In the multivariate analysis, worse self-rated health was the only variable associated with binge drinking in both populations (Prevalence ratios [PR] 0.62; 95\% Cl 0.45-0.85 and 0.57; (0.40-0.83), respectively). On the other hand, two important differences were found: 1) in the metropolitan area of Belo Horizonte, binge drinking was associated with higher school level $[8+$ years] $(P R=1.55 ; 95 \% \mathrm{Cl} 1.07-2.26)$ and functional disability $(P R=0.12) ; 95 \% \mathrm{Cl}(0.02-0.83) 2)$ in Bambuí, binge drinking was associated with being divorced or separated ( $P R=2.49$; $95 \% \mathrm{Cl}$ 1.55-3.99). Conclusions: Among older adults, differences of prevalence and factors associated with binge drinking can be found in a same country, probably due to sociocultural influences.
\end{abstract}

Descriptors: Alcohol drinking; Elderly; Epidemiology, Brazil; Binge drinking; Associated factors

\section{Resumo}

Objetivos: Determinar a prevalência e fatores associados ao consumo episódico excessivo de álcool em duas populações idosas ( $\geq 60$ anos). Método: Foi selecionada uma amostra probabilística de 685 idosos na Região Metropolitana de Belo Horizonte e 642 (92,6\% do total de residentes) idosos na cidade de Bambuí (15.000 habitantes), ambas situadas em Minas Gerais. A variável dependente do estudo foi consumo de $\geq 5$ drinques em uma única ocasião nos últimos 30 dias e as variáveis independentes incluíram características sociodemográficas, rede social de apoio, condições de saúde e usos de serviços de saúde. Resultados: A prevalência deste consumo foi maior na Região Metropolitana de Belo Horizonte (27,0\%) do que em Bambuí (13,7\%). Na análise multivarida, pior percepção da saúde foi a única característica que persistiu associada ao consumo episódico excessivo de álcool em ambas as populações (RP = 0,62; IC95\% 0,45-0,85 e 0,57; 0,40-0,83, respectivamente). Por outro lado, duas diferenças foram encontradas: 1) na Região Metropolitana de Belo Horizonte, o consumo excessivo de álcool apresentou associação significante com maior escolaridade [8+ anos] (RP = 1,55; IC95\% 1,07-2,26) e com incapacidade funcional ( $P R=0,12 ;$ IC 95\% 0,02-0,83); 2) em Bambuí, observou-se associação independente entre esse consumo e ser divorciado ou separado ( $R P=2,49$; IC 95\% 1,55-3,99). Conclusões: Os resultados mostram que diferenças na prevalência e fatores associados ao consumo episódico excessivo de álcool podem ser observadas entre populações de um mesmo país, provavelmente devido a influências socioculturais.

Descritores: Consumo de bebidas alcoólicas; Idoso; Epidemiologia, Brasil; Consumo episódico excessivo de álcool; Fatores associados

\footnotetext{
1 Núcleo de Estudos em Saúde Pública e Envelhecimento (NESPE), Fundação Oswaldo Cruz and Universidade Federal de Minas Gerais (UFMG), Belo Horizonte (MG), Brazil

2 Post-Graduate Program in Health Sciences, Instituto René Rachou, Fundação Oswaldo Cruz, Belo Horizonte (MG), Brazil

3 Department of Preventive and Social Medicine, Faculdade de Medicina, Universidade Federal de Minas Gerais (UFMG), Belo Horizonte (MG), Brazil

4 Department of Mental Health, Faculdade de Medicina, Universidade Federal de Minas Gerais (UFMG), Belo Horizonte (MG), Brazil
}

Financial support: Financiadora de Estudos e Projetos (FINEP) and Fundação de Amparo à Pesquisa do Estado de Minas Gerais (FAPEMIG)

Conflict of interests: None

Submitted: February 14, 2007

Accepted: June 25, 2007

\section{Correspondence}

Elizabeth Uchôa

Laboratório de Epidemiologia e Antropologia Médica Instituto René Rachou da Fundação Oswaldo Cruz

Av. Augusto de Lima, 1715

30190-002 Belo Horizonte, MG, Brazi

E-mail: uchoae@cpqrr.fiocruz.br 


\section{Introduction}

Binge drinking is a public health concern for younger and older subjects. ${ }^{1}$ Nevertheless, only recently binge drinking among the elderly has been in focus as an emerging public health problem. ${ }^{2-5}$ The elderly are more vulnerable to the effects of alcohol in the organism, in comparison with the younger adults, due to physiological changes associated with aging (decrease of the body's water volume, decrease in the functional capacity of the kidneys and the liver), ${ }^{6}$ the increased risk of comorbidity ${ }^{7,8}$ and of drug interactions. ${ }^{7}$ It is recommended that the consumption of alcohol among older adults does not exceed one drink per day, or, not more than seven drinks a week. ${ }^{9}$

An episode of excessive alcohol consumption (binge drinking) is defined as the ingestion of five or more drinks for men and four or more drinks for women on one occasion. ${ }^{10}$ This consumption is associated with alcoholic intoxication, with important physical, psychological and social consequences such as: automobile accidents, suicides, high blood pressure, myocardium infarction, gastritis, pancreatitis, difficulties controlling diabetes and interpersonal violence. ${ }^{11,12}$ Binge drinking is a key indicator of alcoholic abuse, no matter what the habitually consumed quantity is. ${ }^{11}$

Despite of the fact that aging is occurring very fast in the world, especially in middle and low income countries, ${ }^{13}$ population-based studies on factors associated with binge drinking among the elderly are still rare and restricted to high income countries. 5,11,14,15

This study refers to the binge drinking of two elderly male populations of Minas Gerais, one residing in the large metropolitan area of Belo Horizonte and the other residing in a small city named Bambuí. The objective of the study was to determine the prevalence of excessive alcohol consumption and examine the associations existing between this consumption and sociodemographic characteristics, social support, health conditions and use of health services.

\section{Method}

\section{Study areas}

The metropolitan region of Belo Horizonte (RMBH) is composed of around 20 municipalities, representing the third largest metropolitan area in Brazil in terms of population (4.4 million inhabitants) and in economic production. Bambuí is a small town (15,000 inhabitants) located $240 \mathrm{~km}$ from RMBH, also in the state of Minas Gerais. In the former, industrial and commercial activities, typical of large urban centers, predominate. In Bambuí, the main economic activities are agriculture and small commerce.

\section{Study populations}

The sample of the RMBH health survey was designed to produce estimates of the non-institutionalized population. It is a two stage probability sample, using the Brazilian census sector as the primary selection unit and domicile as the sample unit. The sample is based on 7,500 domiciles with 24 thousand dwellers. All residents aged 18 or more years were eligible for the RMBH Health Survey. The data were collected between May $1^{\text {st }}$ and July $31^{\text {st }}, 2003$. The response rate was $79 \%$, and the distribution by sex and age of the participants was similar to that observed among the total RMBH population aged 18 or older. All the participating males of this survey, aged 60 years or more, were selected for the present study. More details about the survey can be seen in another publication. ${ }^{13}$

All the inhabitants aged 60 years or older (1,742 inhabitants) were selected to participate in the Bambuí health survey. The identification of the participants was done by a complete census of the town, conducted by the research team. The response rate was $96 \%$. The participants were similar to the total population in relation to all the sociodemographic characteristics considered. The interviews were answered by the elderly, or by a proxy, when he/ she was unable to participate because of a health problem. More details can be seen in Lima-Costa et al. ${ }^{16}$ All males participating in the Bambuí health survey, aged 60 years or more, were selected for the present study.

The RMBH health survey was approved by the Ethics Committee of the Oswaldo Cruz Foundation in Belo Horizonte, Brazil, in 2003. The Bambuí Study was approved by the Ethics Committee of the Oswaldo Cruz Foundation in Rio de Janeiro, Brazil, in 1996.

\section{Study variables}

The dependent variable of this study is binge drinking, defined as the consumption of five or more alcoholic drinks on a single occasion in the last 30 days. ${ }^{10}$ The questions about alcoholic drinking were based on the US survey "Behavioral Risk Factors Surveillance". ${ }^{17}$ An illustrated card, showing that an alcoholic drink was equivalent to a $350 \mathrm{ml}$ can of beer, a small glass $(120-150 \mathrm{ml}$ ) of wine or a dose (30-50 ml) of distilled liquor (Brazilian cachaça, whiskey and others), was shown to each individual interviewee.

Four groups of exploratory variables were considered: 1) sociodemographic characteristics (age, marital status, number of completed years of schooling); 2) social network (the existence of a person who he/she can count on in difficult moments, frequency of visits of offsprings in the last month and frequency of visits of other relatives in the last month); 3) health conditions (self-rated health, number of chronic conditions based on the report of previous medical diagnosis for: high blood pressure, myocardial infarction, angina pectoris, diabetes mellitus, and arthritis/ rheumatism, and functional disability, which was determined as incapacity to perform at least one or five activities of daily living that characterize extreme dependence, such as bathing, dressing, toileting oneself and moving from the bed to a chair) and 4) use of health service (number of doctor visits in the last 12 months and hospitalizations in the last 12 months). This information was obtained through the interview performed at the participant's home. When a resident was absent during the interview or was unable to participate for some health reason, a proxy was used. The use of a proxy was greater in $\mathrm{RMBH}(28.5 \%)$ than in Bambuí $(7.8 \%)$. For this reason, the use of a proxy was included as a potential confounding variable in this study.

\section{Data analysis}

To analyze data from $\mathrm{RMBH}$, procedures from Stata ${ }^{\circledR}$ for complex samples were used, which made possible the incorporation of giving different weights to the observations (Stata $\left.{ }^{\circledR}, 2001\right) .{ }^{18}$ This procedure was not necessary for the survey of Bambuí, since the participants of this study corresponded to the total population.

Analysis was done separately for each survey. The univariate analyses were based on Pearson's Chi-Square test and multivariate analyses were based on prevalence ratios (PR) estimated by Robust Poisson Regression. ${ }^{19}$ Age (as continuous variable) and who responded to the interview were considered a priori as confounding variables in the study and were included in the initial multivariate models. Those variables that, in the univariate analysis, presented p-value $<0.20$ were included in the initial multivariate models; those ones whose association with binge drinking presented $p$-value $<0.05$ after adjustments for confounders were maintained in the final multivariate models. The analyses were performed using Stata Package ${ }^{\circledR}$, version 9.1.18 


\section{Results}

Six hundred and eighty-five residents in the RMBH and 642 residents in Bambuí (mean age $=68.8$ and 69.0 years, respectively) participated in the study. The schooling level was higher among the former $(34.2 \%$ presented $>8$ complete years of schooling), in comparison with the latter (only $8.6 \%$ presented equivalent schooling level). Marital status was similar in both populations, predominating married subjects, as can be seen in Table 1.

The prevalence of binge drinking was two times higher among residents in the $\mathrm{RMBH}(27.1 \% ; 95 \% \mathrm{Cl}=23.4 \%-31.2 \%)$ than among the residents in Bambuí (13.7\%).

The results of the univariate analysis of the association between binge drinking, sociodemographic characteristics and social network are presented in Table 2. Significant $(p<0.05$ ) association with binge drinking was found for schooling in the RMBH and for marital status and visits of offspring in the last month in Bambuí. Self-rated health was significantly $(p<0.05)$ associated with binge drinking in both populations. Number of chronic diseases and inability to perform activities of daily living was associated with binge drinking in the RMBH, while number of doctor visits and hospitalization in the last 12 months were associated with binge drinking in Bambuí (Table 3).

The final results of the multivariate analysis of the factors associated with binge drinking are presented in Table 4. In RMBH, higher schooling level $[8+$ years] $(\mathrm{PR}=1.55 ; 95 \% \mathrm{Cl}=1.07-2.26)$, worse self-rated health [reasonable, bad or very bad] $(\mathrm{PR}=0.62 ; 95 \% \mathrm{Cl}=0.45-0.85)$ and
Table 1 - Selected sociodemographic characteristics of the participants, by study area

\begin{tabular}{lcc}
\hline $\begin{array}{c}\text { Sociodemographic } \\
\text { characteristics }\end{array}$ & $\begin{array}{c}\text { Metropolitan Region } \\
\text { of Belo Horizonte } \\
\text { Mean (range) or \% }\end{array}$ & $\begin{array}{c}\text { Bambui } \\
\text { Mean (range) or \% }\end{array}$ \\
\hline Age (years) & $68.8(60-97)$ & $69.0(60-93)$ \\
Marital status & 79.4 & 73.0 \\
Married/living together & 5.3 & 8.3 \\
Single & 4.7 & 5.6 \\
Divorced/separated & 10.6 & 13.1 \\
Widow & & \\
Schooling (years) & 35.6 & 63.1 \\
0-3 & 30.3 & 28.3 \\
$4-7$ & 34.2 & 8.6 \\
8+ & & \\
\hline
\end{tabular}

inability to perform activities of daily living ( $P R=0.12 ; 95 \%$ $\mathrm{Cl}=0.02-0.83)$ remained significantly associated with binge drinking after adjustments for confounders. In this analysis, self-rated health ( $P R=0.57 ; 95 \% \mathrm{Cl}=0.40-0.83$ ) and being divorced or separated ( $P R=2.49 ; 95 \% \mathrm{Cl}=1.55-3.99$ ) remained significantly associated with binge drinking in Bambuí.

Discussion

The results of this study showed that the prevalence of binge drinking among the elderly residents of $\mathrm{RMBH}$ was two

Table 2 - Distribution of binge drinking among elderly males in the Metropolitan Region of Belo Horizonte (RMBH) and in Bambui, by sociodemographic characteristics and social network

\begin{tabular}{|c|c|c|c|c|}
\hline \multirow{3}{*}{ Variable } & \multicolumn{2}{|c|}{$\begin{array}{c}\text { RMBH } \\
\text { Binge drinking }{ }^{1}\end{array}$} & \multicolumn{2}{|c|}{$\begin{array}{c}\text { Bambuí } \\
\text { Binge drinking }\end{array}$} \\
\hline & Yes & No & Yes & No \\
\hline & $\%$ & $\%$ & $\%$ & $\%$ \\
\hline \multicolumn{5}{|l|}{ Age (years) } \\
\hline $60-64$ & 31.3 & 68.7 & 16.3 & 83.7 \\
\hline $65-69$ & 28.5 & 71.5 & 14.1 & 85.9 \\
\hline $70-74$ & 28.0 & 72.0 & 13.2 & 86.8 \\
\hline \multirow[t]{2}{*}{$75+$} & 17.1 & 82.9 & 9.8 & 90.2 \\
\hline & \multicolumn{2}{|c|}{$(p=0.114)$} & \multicolumn{2}{|c|}{$(p=0.387)$} \\
\hline \multicolumn{5}{|l|}{ Marital Status } \\
\hline Married or living together & 28.2 & 71.8 & 13.3 & 86.8 \\
\hline Single & 29.5 & 70.5 & 9.4 & 90.6 \\
\hline Divorced or separated & 28.6 & 71.4 & 33.3 & 66.7 \\
\hline \multirow[t]{2}{*}{ Widow } & 17.0 & 83.0 & 10.7 & 89.3 \\
\hline & \multicolumn{2}{|c|}{$(p=0.316)$} & \multicolumn{2}{|c|}{$(p=0.002)$} \\
\hline \multicolumn{5}{|l|}{ Schooling (years) } \\
\hline $0-3$ & 17.7 & 82.3 & 12.7 & 87.3 \\
\hline $4-7$ & 29.7 & 70.3 & 17.1 & 82.9 \\
\hline \multirow[t]{2}{*}{$8+$} & 34.7 & 65.4 & 10.9 & 89.1 \\
\hline & \multicolumn{2}{|c|}{$(p=0.002)$} & \multicolumn{2}{|c|}{$(p=0.282)$} \\
\hline \multicolumn{5}{|l|}{ Can count on someone in difficult times } \\
\hline Always or nearly always & 27.0 & 73.0 & 13.4 & 86.6 \\
\hline \multirow[t]{2}{*}{ Sometimes or never } & 25.2 & 74.8 & 20.8 & 79.2 \\
\hline & \multicolumn{2}{|c|}{$(p=0.795)$} & \multicolumn{2}{|c|}{$(p=0.146)$} \\
\hline \multicolumn{5}{|l|}{ Offspring visits in the last month } \\
\hline$\geq 1$ time a week & 24.8 & 85.2 & 12.7 & 87.3 \\
\hline $1-3$ times a month & 24.9 & 75.1 & 12.8 & 87.2 \\
\hline$<1$ time a month & 33.6 & 66.4 & 25.0 & 75.0 \\
\hline \multirow[t]{2}{*}{ Has no children or lives with all the children } & 30.6 & 69.4 & 9.8 & 81.2 \\
\hline & \multicolumn{2}{|c|}{$(p=0.363)$} & \multicolumn{2}{|c|}{$(p=0.013)$} \\
\hline \multicolumn{5}{|l|}{ Relative visits in the last month } \\
\hline$\geq 1$ time a week & 23.3 & 76.7 & 13.6 & 82.4 \\
\hline 1-3 times a week & 29.6 & 70.4 & 11.3 & 88.7 \\
\hline \multirow[t]{2}{*}{$<1$ time a week } & 27.7 & 72.3 & 15.8 & 84.2 \\
\hline & \multicolumn{2}{|c|}{$(p=0.591)$} & \multicolumn{2}{|c|}{$(p=0.439)$} \\
\hline
\end{tabular}

${ }^{1}$ Consumption of five or more alcoholic beverages on one single occasion in the last month. p-value from Pearson chi-square test 
Table 3 - Distribution of binge drinking among elderly males in the Metropolitan Region of Belo Horizonte (RMBH) and in Bambuí, by self-reported health conditions and use of health services

\begin{tabular}{|c|c|c|c|c|}
\hline \multirow{3}{*}{ Variable } & RMBH & Binge drinking ${ }^{1}$ & \multicolumn{2}{|c|}{$\begin{array}{c}\text { Bambuí } \\
\text { Binge drinking }{ }^{1}\end{array}$} \\
\hline & Yes & No & Yes & No \\
\hline & $\%$ & $\%$ & $\%$ & $\%$ \\
\hline \multicolumn{5}{|l|}{ Self-rated health } \\
\hline Very good or good & 34.5 & 65.5 & 20.0 & 80.0 \\
\hline \multirow[t]{2}{*}{ Reasonable, bad or very bad } & 18.4 & 81.6 & 10.9 & 89.1 \\
\hline & \multicolumn{2}{|c|}{$(p<0.001)$} & \multicolumn{2}{|c|}{$(p=0.002)$} \\
\hline \multicolumn{5}{|c|}{ Number of self-reported chronic diseases } \\
\hline None & 33.2 & 66.7 & 16.6 & 83.4 \\
\hline 1 & 26.7 & 73.3 & 15.5 & 84.5 \\
\hline \multirow[t]{2}{*}{$2+$} & 21.0 & 79.0 & 9.6 & 90.4 \\
\hline & \multicolumn{2}{|c|}{$(p=0.047)$} & \multicolumn{2}{|c|}{$(p=0.077)$} \\
\hline \multicolumn{5}{|c|}{ Inability to perform activities of daily living } \\
\hline No & 28.2 & 71.8 & 14.5 & 85.5 \\
\hline \multirow[t]{2}{*}{ Yes } & 2.8 & 97.2 & 4.5 & 95.5 \\
\hline & \multicolumn{2}{|c|}{$(p=0.020)$} & \multicolumn{2}{|c|}{$(p=0.085)$} \\
\hline \multicolumn{5}{|c|}{ Number of visits to the doctor in the last 12 months } \\
\hline None & 29.5 & 70.5 & 14.1 & 85.9 \\
\hline $1-2$ & 30.2 & 69.8 & 20.4 & 79.6 \\
\hline \multirow[t]{2}{*}{$3+$} & 23.2 & 76.8 & 6.6 & 93.4 \\
\hline & \multicolumn{2}{|c|}{$(p=0.254)$} & \multicolumn{2}{|c|}{$(p<0.001)$} \\
\hline \multicolumn{5}{|l|}{ Hospitalization in the last 12 months } \\
\hline No & 27.9 & 82.1 & 15.1 & 84.9 \\
\hline \multirow[t]{2}{*}{ Yes } & 22.4 & 77.6 & 7.7 & 92.3 \\
\hline & \multicolumn{2}{|c|}{$(p=0.343)$} & \multicolumn{2}{|c|}{$(p=0.046)$} \\
\hline
\end{tabular}

\footnotetext{
${ }^{1}$ Consumption of five or more alcoholic beverages on one single occasion in the last month
}

p-value from Pearson's chi-square test

times greater than that observed among the residents of Bambuí. The prevalence of binge drinking in the latter was similar to that observed among North American elderly males at the beginning of the 1980 s $(15 \%))^{5}$

Binge drinking is greater among males. ${ }^{11,20}$ In the United States in 2002, for example, its prevalence among male adults was three times greater (24\%) than that observed among females (8\%), and considering both genders, the corresponding prevalence was equal to $3.1 \%$ for those aged 65 years or more. ${ }^{20}$ In the present study, only males were considered due to the low prevalence of elderly women who reported binge drinking in $\mathrm{RMBH}(7.3 \%)$ and, above all, in Bambuí (0.4\%). Considering both genders, the prevalence of binge drinking was five times greater in the $\mathrm{RMBH}$ and nearly two times greater in Bambuí (15.4 and 5.7\%, respectively; data not published) than among the elderly of the United States. ${ }^{20}$

There is some evidence that binge drinking decreases among the oldest old. ${ }^{15}$ In the present study, age was not associated with binge drinking in both studied populations.

The association between binge drinking and schooling, or other sociodemographic characteristics is controversial. 5,21,22 Ruchlin $^{22}$ observed that, for elderly persons, living in a large metropolis and having high level of schooling were positively associated with binge drinking. More recently, a multicenter study of younger participants (25-59 years of age) showed that the association between binge drinking and sociodemographic variables could vary among countries and cultures. In most of the 15 countries studied, binge drinking was associated with low schooling level, but in the Latin American countries, this consumption was greater among those with higher scholarity. ${ }^{23}$ The results of the present study are consistent with these observations. The prevalence of binge drinking was greater among the residents of the metropolitan region and, of these, with higher schooling level. But it is important to point out that in Bambuí no association between schooling and binge drinking was observed, indicating that the inconsistency of this association can be observed even among populations of the same country.

The association between marital status and binge drinking is a matter of controversy. In a study performed in the United States, binge drinking was observed to be more frequent among the recently widowed than among the married elderly. The loss of the care of the wife and the control of the same over the drinking habits of the husband was the explanation given for this finding. ${ }^{24}$ In this study,

Table 4 - Statistically significant results of the multivariate analysis of the association between binge drinking ${ }^{1}$ and selected characteristics among elderly male in the Metropolitan Region of Belo Horizonte (RMBH) and Bambui

\begin{tabular}{|c|c|c|}
\hline \multirow{2}{*}{ Characteristics } & RMBH & Bambui \\
\hline & PR (95\%Cl) & PR (95\%Cl) \\
\hline \multicolumn{3}{|l|}{ Marital status } \\
\hline Married or living together & - & 1.00 \\
\hline Single & - & $0.78(0.33-1.88)$ \\
\hline Divorced or separated & - & 2.49 (1.55-3.99) \\
\hline Widow & - & $0.97(0.50-1.87)$ \\
\hline \multicolumn{3}{|l|}{ Schooling (years) } \\
\hline $0-3$ & 1.00 & - \\
\hline 4-7 & $1.45(0.98-2.14)$ & - \\
\hline $8+$ & $1.55(1.07-2.26)$ & - \\
\hline \multicolumn{3}{|l|}{ Self-rated health } \\
\hline Very good or good & 1.00 & 1.00 \\
\hline $\begin{array}{l}\text { Reasonable, bad or very } \\
\text { bad }\end{array}$ & $0.62(0.45-0.85)$ & $0.57(0.40-0.83)$ \\
\hline \multicolumn{3}{|l|}{$\begin{array}{l}\text { Inability to perform } \\
\text { activities of daily living }\end{array}$} \\
\hline No & 1.00 & - \\
\hline Yes & $0.12(0.02-0.83)$ & - \\
\hline
\end{tabular}

(1) Consumption of five or more alcoholic beverages on one single occasion in the last month.

$P R(95 \% \mathrm{Cl})$ Prevalence ratio (95\% confidence Interval) estimated by Robust Poisson Regression and adjusted for all the variables listed in the column. plus age and who responded the interview. 
an association between marital status and binge drinking was not found among the residents of $\mathrm{RMBH}$, but a strong association between this consumption and being divorced or separated was observed in Bambuí. This may be a reflection of the differences in social perception of divorce or separation in the two populations.

Self-rated health is one of the most commonly used indicators in geriatric research because health perception consistently predicts both mortality and functional decline. Among the Bambuí elderly, self-rated health is multidimensional in structure, being influenced by socioeconomic conditions, social support, health status (with emphasis on mental health), and access to/use of health services. ${ }^{25}$ In a study conducted in the United States, binge drinking was lower among the elderly with worse self-rated health. ${ }^{22}$ The results of the present study are in agreement with these observations. Both in $\mathrm{RMBH}$ and in Bambuí, binge drinking was lower among the elderly with worse self-rated health.

A study conducted among elderly North Americans demonstrated that among those younger than 75 years old, having more health problems was associated with a lower consumption of alcohol, while for those older than 75 this consumption was associated with inability to perform activities of daily living. ${ }^{15}$ In this study, the prevalence of binge drinking was significantly lower among the elderly of Bambuí with inability to perform activities of daily living, but this association was not observed in $\mathrm{RMBH}$. No association between this consumption and number of chronic diseases or use of health services was observed in either of the populations.

With relation to social network, none of the variables considered in the present study remained associated with binge drinking after adjustments for confounders, both in RMBH as well as in Bambuí. To our knowledge, there are no other studies that have investigated these associations. A Canadian study on alcohol consumption and psychosocial well-being among the elderly did not find an association between excessive consumption of alcohol (not necessarily binge drinking) and social support. ${ }^{26}$

This study has some advantages. It is a population based study, with high response rates, avoiding selection bias. Because this study is cross-sectional in design, temporal relationships between binge drinking and the exploratory variables is unknown. On the other hand, this design is adequate to estimate prevalence rates, which is the primary objective of our study. Regarding the comparability of results, the research instruments were similar in both surveys. Due to operational reasons, the prevalence of proxy respondents was four times higher in Belo Horizonte in relation to Bambuí, but it seems unlikely that this has influenced the results because the prevalence of binge drinking was similar among those who responded the interview and among those who had their interview responded by a proxy in Belo Horizonte (26\% and 30\%, respectively; $p=0.296)$, as well as in Bambuí (14\% e $12 \%$, respectively; $p=0.686$ ) (not shown).

In summary, the results of this study showed that worse selfrated health was the only characteristic consistently associated with binge drinking in both of the populations. On the other hand, two important differences were observed: 1) in $\mathrm{RMBH}$, binge drinking was associated with higher schooling level and functional disability; 2) in Bambuí, binge drinking was associated with being divorced or separated. These results indicate that, among older adults, differences of prevalence and factors associated with binge drinking can be found in a same country, probably due to sociocultural influences.

\section{Acknowledgments}

This study was supported by grants of the Financiadora de Estudos e Projetos (FINEP) and Fundação de Amparo à Pesquisa do Estado de Minas Gerais (FAPEMIG), Brazil. MF Lima-Costa and E Uchoa are fellows of the Conselho Nacional de Desenvolvimento Científico e Tecnológico (CNPq).

\section{References}

1. National Institute on Alcohol Abuse and aAlcoholism. NIAAA Council approves definition of binge drinking. NIAAA Newsletter. 2004;3:3.

2. Hanson GR, Li TK. Public health implications of excessive alcohol consumption. JAMA. 2003;289(8):1031-2.

3. Breslow RA, Faden VB, Smothers B. Alcohol consumption by elderly Americans. J Stud Alcohol. 2003;64(6):884-92.

4. Blow FC, Barry KL. Older patients with at-risk and problem drinking patterns: new developments and brief interventions. J Geriatr Psychiatry Neurol. 2000;13(3):115-23.

5. Moore AA, Hays RD, Greendale GA, Damesyn M, Reuben DB. Drinking habits among older persons: findings from the NHANES I Epidemiologic Follow-up Study (1982-1984). J Am Geriatr Soc. 1999;47(4):412-6.

6. Vestal RE, McGuire EA, Tobin JD, Andres R, Norris AH, Mezey E. Aging and ethanol metabolism. Clin Pharmacol Ther. 1977;21(3):343-54.

7. Oslin DW. Alcohol use in late life: disability and comorbidity. J Geriatr Psychiatry Neurol. 2000;13(3):134-40.

8. Alcoholism in the elderly. Council on Scientific Affairs, American Medical Association. JAMA. 1996;275(10):797-801.

9. National Institute on Alcohol Abuse and Alcoholism - NIAAA. Alcohol and Aging. Alcohol Alert. 1998;40, 7pp.

10. National Institute on Alcohol Abuse and Alcoholism - NIAAA. Eighth special report to the U.S. Congress on Alcohol and Health. Bathesda, MD: National Institute of Health; 1994.

11. Naimi TS, Brewer RD, Mokdad A, Denny C, Serdula MK, Marks JS. Binge drinking among US adults. JAMA. 2003(1);289:70-5.

12. National Institute on Alcohol Abuse and Alcoholism - NIAAA. Tenth special report to U.S. Congress on Alcohol and Health. Bathesda, MD: National Institute of Health; 2000.

13. Lima-Costa MF. A Saúde dos adultos na Região Metropolitana de Belo Horizonte: um estudo epidemiológico de base populacional. Belo Horizonte: Nespe/Fiocruz/UFMG; 2004. 132p. (www.cpqrr.fiocruz. $\mathrm{br} / \mathrm{NESPE}$ )

14. Mirand AL, Welte JW. Alcohol Consumption among the elderly in a general population. Erie County, New York. Am J Public Health. 1996;86(7):978-84.

15. Wiscott R, Kopera-Frye K, Begovic A. Binge drinking in later life: comparing young-old and old-old social drinkers. Psychol Addict Behav. 2002;16(3):252-5.

16. Lima-Costa MF, Uchoa E, Guerra HL, Firmo JO, Pedro G, Vidigal PG, Barreto SM. The Bambuí health and ageing study (BHAS): methodological approach and preliminary results of a populationbased cohort study of the elderly in Brazil. Rev Saude Publica. 2000;34(2): 126-35.

17. Centers for Disease Control and Prevention (CDC). Behavioral Risk Factor Surveillance (BRFSS) (2001). Acesso: nov. 2004. Disponível em: http://www.cdc.gov/nccdphp/brfss/pdf-ques/2001brfss. pdf.

18. Stata ${ }^{\circledR}$ Statistical Software - computer program. (2001). Release 7.0. College Stations, Stata Corporations, Texas, USA.

19. Zou G. A modified poisson regression approach to prospective studies with binary data. Am J Epidemiol. 2004;159(7):702-6.

20. Centers for Disease Control and Prevention (CDC). Behavioral Risk Factor Surveillance (BRFSS) 2007. Disponível em http://apps.nccd. cdc.gov/brfss/Trends/sexchart.asp?qkey $=10100 \&$ state $=$ US. Acessado em janeiro de 2007

21. Dawson DA, Grant BF, Chou SP, Pickering RP. Subgroup variation in U.S. drinking patterns: results of the 1992 National Longitudinal Alcohol Epidemiologic Study. J Subst Abuse. 1995;7(3):331-44.

22. Ruchlin HS. Prevalence and correlates of alcohol use among older adults. Prev Med. 1997;26(5 Pt 1):651-7. 
23. Bloomfield K, Grittner U, Kramer S, Gmel G. Social inequalities in alcohol consumption and alcohol-related problems in the study countries of the EU concerted action 'gender, culture and alcohol problems: a multi-national study'. Alcohol Alcohol Suppl. 2006;41(1):i26-36.

24. Byrne GA, Raphael B, Arnold E. Alcohol consumption and psychological distress in recently widowed older men. Aust N Z J Psychiatry. 1999;33(5):740-7

25. Lima-Costa MF, Firmo JO, Uchoa E. A estrutura da auto-avaliação da saúde entre idosos: Projeto Bambuí. Rev Saude Publica. 2004;38(6):827-34

26. Graham K, Schmidt G. Alcohol use and psychosocial well-being among older adults. J Stud Alcohol. 1999;60(3):345-51. 